\title{
Pedagogical Mediation and Complexity. A Perspective on the Training of Economists
}

\author{
https://doi.org/10.3991/ijet.v16i16.23305 \\ Isabel Cristina Rivera-Lozada ${ }^{1}$, Oriana Rivera-Lozada ${ }^{2}\left({ }^{\varpi}\right)$, \\ César Antonio Bonilla-Asalde ${ }^{2}$ \\ ${ }^{1}$ Universidad del Cauca, Colombia \\ ${ }^{2}$ South American Center for Education and Research in Public Health, Universidad Norbert \\ Wiener-Lima, Perú \\ Oriana.rivera@uwiener.edu.pe
}

\begin{abstract}
This research seeks to design a pedagogical strategies proposal for the economic sciences learning at a Faculty of Economics in Colombia; Methods: derived from complex thinking has three phases: resonance, biolearning-relationality and holographic phase. These involve the following examples of pedagogical mediation: flipped classroom, gamification, sociopedagogical cartography, virtual learning objects and Feeling methodology with the pillars of bio-pedagogy, knowledge construction, critical thinking and social transformation; the research shows the achievement of learning objectives in economics in line with the bio-pedagogical vision, using the proposed pedagogical mediation; Linking pedagogical innovations based on biopedagogy, allows improving the academic objectives proposed for the training of economists.
\end{abstract}

Keywords - pedagogical mediation, bio-pedagogy, education complexity

\section{Introduction}

Economic Sciences are usually taught through traditional pedagogical mediation, which led us to research on the ones that foster critical thinking in students and offer training that makes social transformation possible. Consequently, five examples of mediation that incorporate ICT were proposed, as well as play-based elements that can be adjusted to the learning process of today's economy.

Introducing ICT in the classroom improves learning and academic performance levels. It also decreases school retention rates. This includes Facebook pages [1], teacher training strategies and the existent relationship between these and the integration of technologies with academic content [2]. The impact of new educational technologies promotes knowledge acquisition, analysis and contextualization for both teachers and students [3]. Some methodologies for measuring technological impact on learning indicate that it increases productivity, reduces costs and increases the demand for academic programs [4]. The use of blended learning as a teaching-learning method makes it possible to overcome some of the limitations of traditional teaching 
regarding limits of space and time; in addition, it helps to reduce the costs of teaching staff and equipped classrooms [5].

Some studies show that types of mediation such as gamification can be an efficient strategy to reveal the clarity of the students' theoretical knowledge through the use of ICTs, but there are shortcomings regarding the implementation of content and innovation by the participants [6]. Regarding video games, they are useful for addressing issues related to the risks to which students are exposed on the Internet, they can provide relevant information to navigate safely, build digital narratives and encourage collaborative and autonomous learning [7].

All previous research agrees on the importance of the Internet as a valuable tool for the process of innovation and transformation of the teaching model implemented in higher education institutions [8].

The research is supported by bio-pedagogy and pedagogical mediation as theoretical references. Regarding the methodological approach, complex thinking enables articulation, relationality and contextualization to achieve something more than what is known in advance [9]. This study seeks to reflect on the minimum topics required to meet the learning objectives in the teaching of economic sciences that promote autonomous learning in students. Therefore, flipped classroom, gamification, sociopedagogical cartography, virtual learning objects and the Feeling methodology are proposed as innovative pedagogical strategies for economics learning in 21 st century society.

Finally, this research recognizes the little exploration in Economics professional training regarding linking curricular content with pedagogical innovations, as well as the necessary articulation of these types of mediation with academic objectives, the achievement of critical thinking, the collective construction of knowledge and the transformation of society, reflecting the pillars of bio-pedagogy [10].

\section{Methodology}

It articulates conceptual interpretations proposed in the systems theory [11] and complexity [12] with the design of pedagogical strategies that put the theoretical approach proposed into discussion.

\subsection{Resonance phase}

It proposes the principles, criteria and characteristics of the pedagogical design as it shows the affectation capacity that theoretical construction has on the pedagogical practices, students' attitude and academic results in order to start a recursive loop of learning actions of positive reception. This phase aims to identify pedagogical efforts and resonance in the learning process, shown in terms of scores as a positive indicator of the pedagogical design. 


\subsection{Bio-learning and relationality phase}

It articulates the understanding of life as a self-organizing learning system with the holistic principle of relationality that integrates the ways of being, thinking, feeling and acting with the diversity of points of view proposed in the curriculum of Economics programs. This required to hold a focus group with professors that highlighted the tensions inherent in the diversity of perspectives and focused the discussion on the points of academic convergence.

\subsection{Holographic phase}

It involves the part that is in the whole, as well as the whole inscribed in each part that integrates it. This phase seeks to rescue the pedagogical components within the framework of its own pedagogical strategy and interprets the results. Thus, integration is expressed in those pedagogical strategies that make it possible to achieve the common academic objective and incorporates the different viewpoints regarding training in economics.

\section{Biopedagogy of learning}

Are the social sciences, particularly economics, based on an adequate understanding of the nature of the human learning process, and on what determines the diversity of human behavior? And if they are not, could they be? [13]. Such questions are still valid and invite reflection on the learning processes and the work in the classroom to facilitate learning.

Bio-pedagogy favors ways for human beings to know not only by using their reasoning but also by using a place where they have their emotions, their soul - as the place of affection - and of self-awareness that can be understood as that quality that allows us to think of ourselves and that is placed somewhere between the brain and the culture of which we are part" [14]. Pedagogy has responded to competitiveness and profit by neglecting life as the center and meaning of learning processes and with it, the mechanisms through which living organisms create and repair their own elements, that is, autopoiesis as a basic and distinctive property of living beings $[15,16]$.

The recognition of self-organization and autopoiesis processes shows the capacity of living beings to learn and breaks the teaching paradigm that implies the passive assumption of information and knowledge. It makes possible the democratization of knowledge by facilitating the bidirectionality of learning by recognizing the student body as peers with whom to recreate and build new knowledge. It reaffirms the active participation of educators and learners in the transformative pursuit of social dynamics and feeds back the autopoietic capacity through learning communities as an extension of the school [17].

The task of educating from a bio-pedagogical perspective, that is, through biolearning, challenges teachers on what to do to achieve it. To this end, the pedagogical mediation of the education is proposed, which conceives the teaching subjects as active interlocutors in the construction of meaning. It refers to the treatment of con- 
tents and forms of expression of the different subjects in order to make possible the pedagogical practice, within the horizon of an education conceived as participation, creativity, expressiveness and relationality [18].

Although mediation depends on teachers' capacity and passion who recreate the staging of knowledge, it implies a dialogical process with students' knowledge and expertise, as well as the proposed aesthetics for the understanding and apprehension of knowledge. It harmonizes the need for creating knowledge with the aesthetic mediation to achieve it. In this sense, it begins with the treatment of the subject by defining contents, concepts, location and context, to continue with the mediation of the content.

Pedagogical mediation requires to respond to the technological advances and the interrelationships that the millenials, Generation $Z$ and those to come incorporate into the learning processes in such a way that the education advances pari passu with the technology of the moment. It takes into account the behaviors, tastes and generational preferences. Thus, this mediation reinforces the necessary conditions for a proper education of the planetary era in terms of strengthening the conditions of possibility of the emergence of a world society composed of protagonists citizens, consciously and critically committed to the construction of a planetary civilization [19,20].

Studies on pedagogical mediation have researched into its effects on professional degrees [21], or evaluated the pedagogical practice [22], teaching strategies and learning styles [23]. In other cases, they developed stimulation programs [24] or sought to strengthen teacher training in terms of program design, analysis and production as a key strategy to improve student learning [25]. They also focused on pedagogical strategies to minimize student dropout [26] linking families and the community [27].

On the other hand, they also worked on learning proposals ([28, 29], with pedagogical practices such as collaborative work, debates, discussions, among others.

Undoubtedly, the discussions on mediation are not exclusive and recognize the importance of incorporating attractive types of mediation which are linked to the interests of the new generations in the learning processes and can account for creative and innovative proposals and incorporate ICT in the classroom, but do not involve the development of critical thinking necessarily.

\section{Searching for the pedagogical south}

The vast majority of university teachers are professionals with little pedagogical training and the faculties of economics are not the exception. This situation has led to individual and institutional efforts to promote pedagogical innovations based on educational practices, but they do not respond to collective and intentional reflections that support the achievement of the learning objectives of the academic program.

Learning is only possible when students are committed to their own learning process [30]. In this sense, bio-pedagogy enables teachers to encourage their students to have a sense of commitment, to adapt to changing environments and to motivate innovation and creativity. 
Similarly, it recognizes the innate learning capacity of all living beings and admits learning through the senses, through values and with the active cooperation of those who participate in the educational process; it fosters the formation of ethical and fair professionals according to the seven knowledges necessary for the education of the future [31, 32].

This approach generates uncertainty given that there is absence of a methodological guide to follow. It is the path that has no doors and therefore thousands of paths lead to it [19], so there is always the open question of how to do it. Beyond offering certainties, it respects autonomy and promotes creativity.

Mediating the educational process pedagogically implies that we have to conceive the subjects of teaching as active interlocutors in the construction of meaning [33]. Thus, defining the meaning of studying economy is a continuous task that renews the teachers' commitment and seeks the learners' permanent love.

Mediation has two moments. 1. Content: it reflects on the minimum required topics which are fundamental to the achievement of the learning objectives in each course and the contributions to the achievement of the meaning of the program. These contents need to have a dialog with the learners' context, seeking to trigger self-learning processes. As far as possible, mediation aims to make the treatment of the topic recurrent in order to address a variety of horizons of understanding. Finally, it seeks to be problematic as a permanent way of encouraging a critical attitude and contrasting criteria with the reality or proposed theory.

In this perspective, the revised economic program includes the minimum required disciplines: micro, macro, econometrics and economic thinking which complements with courses in the regional economic, environmental and alternative fields through which it broadens the field of interpretation, contextualizes knowledge, contrasts reality and proposes models, policies and/or alternatives.

2. Aesthetic mediation: it seeks to reflect the joy of learning in the field of economics. This moment looks for creativity and challenges the seduction and enchantment of the learning proposal. Although educational innovations emerge in response to trends, needs and preferences, not all the teaching staff is involved in them, either through ignorance or uncertainty.

\section{Results}

\subsection{Flipped classroom}

It considers learners to be the center of the learning process and recognizes learning happening outside the classroom [34]. It builds knowledge beyond the rote learning promoted by the traditional education model and puts models, theories and proposals into practice, resulting from economy theories, in addition to the reconstruction and enrichment of the context-based knowledge. Knowledge construction is present in the elaboration of the guides and selection of practical and dynamic materials/authors, with multimedia contents in topics such as consumer theory, monetary and fiscal theory, welfare theory, alternative models of development, and regional economy that 
encourage the interaction of knowledge, customs and economic perceptions of the community with the proposed authors. It recognizes our own rhythms to construct, reconstruct and deconstruct economic knowledge incorporating ICTs in practical exercises that simulate the impact of policies focused on poverty and equality, unemployment, balance of payments, exchange policy, interest rate, investment portfolio, among others.

Similarly, flipped classroom makes students responsible for what happens inside and outside the classroom by giving them a leading role in learning, with a positive effect on the skills developed for the transformation of economic contexts [35]. It approaches the professional practice as policy makers or economic agents of change, with ethical sense and capacity to apply public policies as well as to execute economic, social and environmental projects [36].

\subsection{Gamification}

It integrates games with ICT to explore and enhance creativity in the learning process of economics The playful simulations promote the knowledge construction in the development of economics, social and environmental projects. This mediation adjusts to the rhythm of learning by giving different degrees of difficulty.

The game 3rd World Farmer: The Farmers of the Third World contributes to decision making in a scenario of social, political and economic instability [16]. It offers simulation of practices for the application of resource allocation and shows the results of the decisions. The Monetary Policy Game allows students to assume the role of presiding over a central bank with the aim of achieving financial stability by setting a reference interest rate. It facilitates the learning of monetary theories with the consequent effects on variables such as inflation, investment, employment, among others. It is possible to develop critical thinking by contrasting and applying economic theories in the game Six Hats to Think, where they solve problems by considering different perspectives and linking topics related to the labor market, state intervention, measures to get out of the crisis, the situation of SMEs, globalization, among others [16, 37].

This type of pedagogical mediation favors the reorientation of economic policies in favor of conditions of equity and social justice. The student player is capable of transforming social realities with a proposal of ludic-critical thinking which promotes social and economic responsibility for the promotion of policies linked to the expansion living beings' freedoms in the quest for improvement of levels of social harmony through the enjoyment of rights such as health, housing and education [38].

\subsection{Socio-pedagogical cartography}

It has its origins in the critical perspective of education by allowing the interpretation of the community reality of a group of people based on their own protagonism. The information is recorded, documented and interpreted according to the social and cultural context according to models that represent the systems of relations in a terri- 
tory and lead to reflection on the events and the environment's needs with the use of ecosystem-population, temporal-social and thematic maps [39].

It is possible to use different routes to build the maps that can be used in regional development courses, economic planning, environmental economics, economic geography and project evaluation, with the proposal of a construction guide and interpretation of the map; a provocative question facilitates the articulation of economic knowledge with one's own knowledge, promoting critical thinking and teamwork, and even sharpening the perceptions resulting from the mapping exercise by the resulting understanding of social, cultural, ethnic, environmental and economic phenomena.

In addition, it contrasts the realities with statistical information to broaden the regional multidisciplinary interpretative focus. ICTs applied to social cartography facilitate the understanding of economic concepts and theories learned in the classroom as well as autonomous learning [40], in courses on economic geography, economic planning and regional development.

\section{$5.4 \quad$ Virtual Learning Objects (VLO)}

They are a type of virtual mediation that are designed with a learning purpose. VLO are useful for different educational proposals that develop research projects and integrate information and communication technologies. A large number of people can access and use them simultaneously, which makes them ideal for classroom work due to the accessibility through metadata and in different platforms and contexts [41].

VLO include formulation, planning, analysis, engineering, page generation, testing, and evaluation [42]. They are present in at least three dimensions: pedagogical, technological, and interactive. VLO are characterized by being reusable, flexible, versatile, functional, interoperable, durable, and accessible.

The use of this mediation encourages and promotes the use of ICT and the tools available on the web; it increases the reserves in the VLO repositories, facilitates the monitoring of learning progress, and enables the inclusion of diverse knowledge perspectives, considering that smartphones, tablets, and computers have become essential objects [43]. They are virtual materials that are consulted and/or distributed via Internet, with clear educational purposes and have descriptive metadata to facilitate their cataloguing. They offer a diversity of options that promote creativity, flexibility and contextualization of options, which teachers can use in order to offer learning alternatives to students [44].

From an economic perspective, this mediation can be incorporated into mathematics and its applications, microeconomics, measurement techniques, macroeconomics, project formulation and evaluation. In the case of mathematics, VLO facilitate the ability to relate the mathematical competence to the design of exercises; in addition, this mediation promotes the type of mathematical thinking that is tested in the virtual environment [45], as well as the achieving of a massive coverage without discriminating people with a professional level in all the categories of social condition [46]. 


\subsection{Feeling methodology}

It encourages students to think about innovative solutions and formulate them regarding economic problems inside and outside the classroom. It makes possible knowledge construction and helps students be critical about the economic reality from their own perspective. Students put into practice the trips that The Little Prince, by Antoine de Saint Exupéry, take in five phases: prepare the trip, take off, fly, explore and land [47].

Students prepare the trip by defining the academic resources and economic knowledge they have, then they take off by asking questions about the knowledge they want to deepen in economic matters. For this reason, they suggest topics related to economic thinking, finance, money and banking, and economic policy, among others.

They can use games like Monopoly, Tío Rico (or Rich uncle, Scrooge McDuck) and more than luck cards to improve their economic knowledge and be critical of particular realities. Students learn and question the financial system, fiscal and monetary policy, being able to fly by applying ideas, solutions and expressing feelings about situations that require critical economic thinking.

This methodology explores the learning process by creating products related to export plans, socioeconomic profiles, financial analysis, among others, at the same time it is able to receive collective contributions (feeling play). In addition, it materializes the economic knowledge in a learning matrix with the objective of reinterpreting reality from the feeling-thinking economic perspective.

The feeling methodology promotes students who transform social reality by offering economic and social alternatives to the problems of the dominant economic system, allowing them to express the feelings resulting from this type of activity. The management of emotions has positive implications in students' learning [48], they help future economists become prepared to make optimal decisions, in terms of economic policy, that contribute to the construction of a more equitable society with social justice.

\section{Conclusions}

Although the 21st century is characterized by the revolutions in biotechnology and information-technology, university classrooms are not following these major transformations. Many of the learning processes still focus on teachers as a leading figure, refusing to give this learning responsibility to those who, instead of only receiving it, need to experience it, and therefore learning to transform it. Thus, the new methodologies employed by teachers with ICT support respond to the diversity of needs and styles of each student [17]. For this reason, it is pertinent to design pedagogical strategies that offer routes of pedagogical mediation in specific disciplinary fields, such as, in this case, the economic one.

Pedagogical strategies cannot be a sort of additional aspects resulting from the desire to incorporate pedagogical innovations in the classroom. They respond to the 
achievement of the program's learning objectives and seek to integrate knowledge contextualized to the social realities of those who participate in the learning process.

The inclusion of new methodologies with ICT support in the university environment should lead students to a critical, dynamic and broad environment [28], allowing them to seek, recreate and produce knowledge adjusted to local and global appropriations.

The pedagogical mediations proposed for the economists' training sought to promote the achievement of three learning objectives which are characteristics of biopedagogy such as the construction of knowledge, critical thinking and social transformation [49]. The mediation incorporate playfulness, creativity, ICT, as well as the inclusion of diverse perspectives; that is why the flipped classroom, gamification, virtual learning objects, socio-pedagogical cartography and the feeling methodology were proposed.

This research recognizes the little exploration in the field of economic training when linking curricular content with the presented pedagogical innovations, in articulation with academic objectives that reflect the pillars of bio-pedagogy [10]. Therefore, beyond offering recipes on how to introduce these strategies in the economists' training classrooms, it is open to creative proposals that take into account pedagogical innovations that facilitate learning and that are in line with the learning objectives, contributing to the deepening of knowledge in the field of economics [49].

\section{References}

[1] Patrão, C., \& Dias de Figuerido, A. (2018, Marzo 31). A social web based pedagogical strategy for teaching journalism in higher education. Revista de Educación a Distancia, 57(8). http://dx.doi.org/10.6018/red/57/8

[2] González Isasi, R. M. (2010). Estrategias de formación de profesores para el uso didáctico de la tecnología. Revista de medios y educación, (37), 197-208. https://recyt.fecyt.es/ index.php/pixel/article/viewFile/61410/37423

[3] Meza Meza, A. M., \& Cantarell Zaldivar, L. (2002, noviembre 11). Importancia del manejo de estrategias de aprendizaje para el uso educativo de las nuevas tecnologías de informaicón y comunicación en educación Mistica. https://doi.org/10.35376/10324/12036

[4] Ávila Fajardo, G. P., \& Riascos Erazo, S. C. (2011). Propuesta para la medición del impacto de las TIC en la enseñanza universitaria. Eduación y educadores, 14(1), 169-188. https://doi.org/10.5294/edu.2011.14.1.9

[5] Contreras Bravo, L. E., Gonzáles Guerrero, C., \& Fuentes López, H. J. (2011). Uso de las TIC y especialmente del Blended Learning en la enseñanza universitaria. Educación y Desarrollo social, 5(1), 151-160. https://doi.org/10.18359/reds.898

[6] Karam Rozo, J. M., Buitrago Martin, A. L., Fagua Fagua, A. P., \& Romero Avila, Y. D. (2013). Estrategias de gamificación aplicadas al diagnóstico de la incorporación pedagogica de las TIC en una comunidad académica. Cultura, eduación y sociedad, 4(1), 55-74. https://revistascientificas.cuc.edu.co/culturaeducacionysociedad/article/view/972

[7] Betancur, S., Carmona, L., Contreras, R., Karam, J. M., Maestre, N., Romero, Y., \& Uribe, S. (2014). Videojuegos y TIC como estrategias pedagógicas: formación para el uso seguro de internet. Cultura, Eduación y Sociedad, 5(1), 91-107. https://revistascientificas.cuc .edu.co/culturaeducacionysociedad/article/view/997 
Paper-Pedagogical Mediation and Complexity. A Perspective on the Training of Economists

[8] Moreira Area, E. (2000). ¿Qué aporta el internet al cambio pedagógico en la educación superior?. Redes multimedia y diseños virtuales, 128-135. http://eduteka.icesi.edu.co /gp/upload/Internet\%20y\%20el\%20cambio\%20pedagogico.pdf

[9] Morin, E., \& Pakman, M. (1994). Introducción al pensamiento complejo. Barcelona: gedisa.

[10] Flores Davis, L. E., (2012). Aprendiencia en la docencia y construcción de conocimiento biopedagógico. Revista electrónica Educare, 16(2), 85-93. https://doi.org/10.15359/ree.16$\underline{2.5}$

[11] Von Bertalanffy, L. (1993). La teoría general de los sistemas. Fondo de cultura económica.

[12] Morín, E. (2007). Complejidad restringida, complejidad general. Sostenible. (9), 23-49. https://upcommons.upc.edu/bitstream/handle/2099/3883/Complidad\%20restrinjida\%20co mplejidad\%20general.pdf?sequence $=1 \&$ is Allowed $=\mathrm{y}$

[13] Maturana, H., \& Varela, F. (2003). El árbol del conocimiento, las bases biológicas del entendimiento humano. (1ra ed.) Lumen.

[14] Morín, E. (2003). La humanidad de la humanidad: la identidad humana (1ra ed.) Ediciones Cátedra

[15] Berdugo Solano, B. Z. (2013). Educación y aprendizaje desde la biopedagogía, perspectivas de cambio para los procesos educativos. Caminos Educativos, 2(2), 103-111. http://revistas.ucundinamarca.edu.co/index.php/Caminos_educativos/article/view/75. https ://doi.org/10.36436/22564527.252

[16] Lopez, A. (2016, febrero 11). Maturana para principiantes: la biología del amar y del conocer. El definido. https://eldefinido.cl/actualidad/plazapublica/6480/Maturana-y-laBiologia-del-Amar-y-del-Conocer/. https://doi.org/10.2307/j.ctvt7x73x.5

[17] De Mello Rodrigues, R. (2011). Comunidades de aprendizaje: democratización de los centros educativos. Tendencias pedagógicas, (17), 3-18. https://dialnet.unirioja.es/descarga /articulo/3653540.pdf

[18] Guitiérrez Perez, Fransisco., \& Prieto Castillo, Daniel. (1993). La mediación pedagógica, apuntes para una educación a distancia alternativa (2da ed.). Instituto de investigaciones y mejoramiento educativo.

[19] Morin, E. (2003). Da necessidade de um pensamento complexo. Para navegar no século $X X I, 2,19-42$.

[20] Sari, R., Sumarmi, S., Astina, I., Utomo, D., \& Ridhwan, R. (2021). Increasing Students Critical Thinking Skills and Learning Motivation Using Inquiry Mind Map. International Journal of Emerging Technologies in Learning (iJET), 16(3), 4-19. https://doi.org/10.3991 lijet.v16i03.16515

[21] Vivar, D. M., \& Fernández, M. (2019). Ante los nuevos retos educativos: profesorado digitalmente competente. Crianças, famílias e tecnologias. Que desafios? Que caminhos?, 110-121.

[22] García Cabrero, Benilde., Loredo Enríquez, Javier., \& Carranza Peña, Guadalupe. (2008). Análisis de la práctica educativa de los docentes: pensamiento, interacción y reflexión. $R e-$ vista electronica de investigación educativa, 1-15. https://www.redalyc.org /pdf/155/15511127006.pdf . https://doi.org/10.7203/relieve.9.1.4351

[23] Donado Tolosa, A. (2014). Epistemología para la investigación del texto escolar. https://doi.org/10.15665/re.v12i1.199

[24] Porta, ME (2012). Un programa de intervención pedagógica en conciencia fonológica. Efectos sobre el aprendizaje inicial de la lectura. Revista de orientación educaciona, (50), 93-111.https://doi.org/10.5944/reop.vol.28.num.2.2017.20117 
[25] Marcelo, C. (2007). Propuesta de estándares de calidad para programas de formación docente a través de estrategias de aprendizaje abierto y a distancia. ORLEAC-UNESCO. https://www.oei.es/historico/pdfs/modelo_aad_unesco.pdf

[26] Vélez, A., \& López Jiménez, D. F. (2004). Estrategias para vencer la deserción universitaria. Educación y educadores. (7), 177-203. https://www.redalyc.org/articulo.oa?id=8340 $\underline{0712}$

[27] Espínola Hoffman, Viola., \& Claro Stuardo, J. P., (2010). Estrategias de prevención de la deserción en la educación secundaria: perspectiva latinoamericana. Revista de educación, 257-280. http://repositorio.minedu.gob.pe/handle/123456789/1200

[28] Pérez Sánchez, B., \& Salas Madriz, F. (2009, abril 30). Hallazgos en investigación sobre el profesorado universitario y la integración de las TIC en la enseñanza. Actualidades investigativas en investigación, 9(1). https://www.redalyc.org/pdf/447/44713054006.pdf . https://doi.org/10.15517/aie.v9i1.9381

[29] Chamorro, A. J., Gonzáles M. H., \& Gómez, A. M. (2008). Las prácticas pdagógicas que construyen conocimiento colectivo en el aula con estudiantes de pregrado de tres universidades de Bogotá. [Tesis de maestría, Universidad de La Salle] Repositorio Universidad de La Salle. https://ciencia.lasalle.edu.co/cgi/viewcontent.cgi?article=1607\&context= maest_docencia. https://doi.org/10.4272/978-84-9745-219-9.ch42

[30] Prado, C., \& Gutiérrez, F. (2004). Germinando humanidad: pedagogía del aprendizaje. Save the children

[31] Morín, E. (1999). Los siete saberes necesarios para la educación del futuro. Santillana. https://doi.org/10.37354/riee.2003.033

[32] Maturana, H. (1999). Transformación en la convivencia. Dolmen ediciones.

[33] Moreira Area, E. (2000). ¿Qué aporta el internet al cambio pedagógico en la educación superior?. Redes multimedia y diseños virtuales, 128-135. http://eduteka.icesi.edu.co/gp/ upload/Internet\%20y\%20el\%20cambio\%20pedagogico.pdf

[34] Escartín, I. A., \& Claver, N. D. (2018). Dar'la vuelta'a la enseñanza. Una experiencia de Flipped Classroom en Economía Pública. e-Publica, (22), 51-75.

[35] Bishop, J. L., \& Verleger, M. A. (2013, June). The flipped classroom: A survey of the research. In ASEE national conference proceedings, Atlanta, GA (Vol. 30, No. 9, pp. 1-18).

[36] Sen, A. (2000). El desarrollo como libertad. Gaceta ecológica, (55), 14-20.

[37] Hendrik, H., \& Hamzah, A. (2021). Flipped Classroom in Programming Course: A Systematic Literature Review. International Journal of Emerging Technologies in Learning (iJET), 16(2), 220-236. https://doi.org/10.3991/ijet.v16i02.15229

[38] Yamani, H. A. (2021). A Conceptual Framework for Integrating Gamification in eLearning Systems Based on Instructional Design Model. International Journal of Emerging Technologies in Learning, 16(4). https://doi.org/10.3991/ijet.v16i04.15693

[39] Barragán Giraldo, D. F., \& Amador Báquiro, J. C. (2014). La cartografía socialpedagógica: una oportunidad para producir conocimiento y re-pensar la educación. Itinerario educativo, 28(64), 127-141. https://doi.org/10.21500/01212753.1422

[40] Orrego-Riofrío, M., \& Aimacaña-Pinduisaca, C. J. (2018). Herramienta multimedia educaplay como recurso didáctico en el proceso enseñanza-aprendizaje de química y física general. Polo del Conocimiento, 3(10), 44-57. http://dx.doi.org/10.23857/pc.v3i10.729

[41] Friesen, N. (2004). Three objections to learning objects. Online education using learning objects, 59-70. https://cutt.ly/JiBgMNv

[42] O'Connor, R., Baddoo, N., Cuadrado-Gallego, JJ, Muslera, RR, Smolander, K. y Messnarz, R. (Eds.). (2009). Mejora de procesos de software: $16^{\mathrm{a}}$ Conferencia Europea, EuroSPI 2009, Alcalá (Madrid), España, 2-4 de septiembre de 2009, Actas (Vol. 42). Springer Science \& Business Media. https://doi.org/10.1007/978-3-642-04133-4 
[43] Dallos Lizcano, A. (2010). Prototipo de objeto virtual de aprendizaje para la ejercitación en matemáticas de primer grado de educación básica. Revista Colombiana de Educación, (58), 96-115. https://www.redalyc.org/pdf/4136/413635664005.pdf. https://doi.org/10.33 304/revinv.v01n1-2013002

[44] Galvis, P., (2018). Diseño didáctico de un OVA para apoyar el aprendizaje del concepto de derivada con estudiantes de II semestre del programa de Economía de la Universidad del Cauca, Corporación universitaria Comfacauca - Unicomfacauca [tesis de especialización no publicada]. Universidad del Cauca. https://doi.org/10.17533/udea.esde.v75n165a10

[45] Gutiérrez Mendoza, L., Buitrago Alemán, M. R., \& Ariza Nieves, L. M. (2017). Identificación de dificultades en el apredinzaje del concepto de la derivada y diseño de OVA como mediación pedagógica. Revista científica general José María Córdova, 15(20), 137 153. http://www.scielo.org.co/pdf/recig/v15n20/1900-6586-recig-15-20-00137.pdf. https:// doi.org/10.21830/19006586.170

[46] Ruiz, A. P. (2011). El modelo docente universitario y el uso de nuevas metodologías en la enseñanza, aprendizaje y evaluación The educational model at university and the use of new methodologies for teaching, learning and assessment. Revista de educación, 355, 591604. https://doi.org/10.33262/concienciadigital.v4i1.2.1591

[47] Durlak, J. A., Weissberg, R. P., Dymnicki, A. B., Taylor, R. D., \& Schellinger, K. B. (2011). The impact of enhancing students' social and emotional learning: A meta-analysis of school-based universal interventions. Child development, 82(1), 405-432. https://doi .org/10.1111/j.1467-8624.2010.01564.x

[48] Castillo Cedeno, I., \& Castillo Cedeno, R. (2013). La mediación biopedagógica desde una perspectiva ética. Revista Electrónica Educare, 17(2), 111-121. https://www.scielo.sa.cr/ pdf/ree/v17n2/a08v17n2.pdf. https://doi.org/10.15359/ree.17-2.7

[49] Montes de Oca Recio, N., \& Machado Ramírez, E. F. (2011). Estrategias docentes y métodos de enseñanza-aprendizaje en la Educación Superior. Humanidades médicas, 11(3), 475-488.

\section{Authors}

Isabel Cristina Rivera-Lozada is an economist, doctor in education, researcher and teacher at the Universidad del Cauca, Colombia. She is a national and international consultant in the design of flexible and non-formal formal education models. Active researcher on issues of education, gender, conflict, health economics and entrepreneurship in Latin American research groups and social organizations. He is currently a member of the Central Curricular Committee of the University of Cauca and a member of the editorial committee of the Research Journal of the Norbert Wiener Private University and the Feminist Economics Board of Cauca (irivera@unicauca.edu.co).

Oriana Rivera-Lozada Researcher in Epidemiology, public health and Health Education. She has the qualification of CONCYTEC Researcher (National Registry of Researchers in Science and Technology, RENACYT, no. P0011631, Carlos Monge Category). Among its scientific production, it has books and scientific articles published in important databases.

César Antonio Bonilla-Asalde Research, with experience in respiratory diseases, Public health and epidemiology, project management in TB, MDR TB and HIV TB, university teaching and research, Hospital management. Former General Director of 
the Daniel Alcides Carrión Callao Peru National Hospital. Former National Coordinator of the National Health Strategy for the Prevention and Control of Tuberculosis in Peru (Ministry of Health-PNT) (Cesar.bonilla@uwiener.edu.pe).

Article submitted 2021-04-14. Resubmitted 2021-05-20. Final acceptance 2021-05-21. Final version published as submitted by the authors. 